\section{Exax \\ SciencePark Research, Organization \& Counseling \\ International Journal of Learning and Teaching}

Volume 08, Issue 1, (2016) 20-29

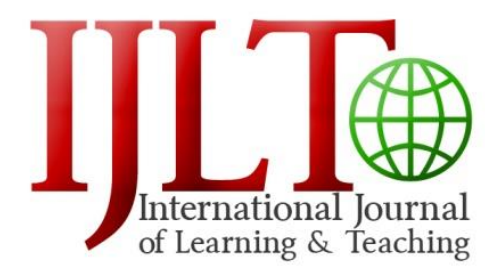

http://sproc.org/ojs/index.php/ijlt

\title{
Factors affecting the effectiveness of thai secondary world class standard school
}

Kanokorm Somprach ${ }^{*}$, Faculty of Education, Khon Kaen University, Khon Kaen and 40002, Thailand Thanomwan Prasertcharoensuk, Faculty of Education, Khon Kaen University, Khon Kaen and 40002, Thailand Tang Keow Ngang, International College, Khon Kaen University, Khon Kaen and 40002, Thailand

\section{Suggested Citation:}

Somprach, K., Prasertcharoensuk, T., \& Tang, K.N. (2016). Factor affecting the effectiveness of thai secondary world class standard school. International Journal of Learning and Teaching. 8(1), 20-29.

Received November 10, 2015; revised December 17, 2015; accepted January 11, 2016;

Selection and peer review under responsibility of Prof. Dr. Hafize Keser, Ankara University, Ankara, Turkey.

${ }^{\circ} 2016$ SciencePark Research, Organization \& Counseling. All rights reserved.

Abstract

This study designed to explore the association and effect of administrative factors affecting the effectiveness of Thai World Class Standard Schools. A total of 375 samples were selected by using stratified random sampling. Researchers employed a questionnaire as a research instrument to collect data. Data was analyzed using descriptive and inferential statistics such as percentage, mean score, standard deviation and stepwise multiple regression analysis. The findings of the study revealed that all the factors affecting the effectiveness of Thai World Class Standard Schools were at high level. Strategic planning was identified as having the highest mean score whereas teacher professional development factor was found to have the lowest mean score. The results also revealed that there were four significant predictors of the effectiveness of Thai Secondary World Class Standard Schools. These four significant predictors were the use of information and communication technology $\left(\mathrm{X}_{8}\right)$, teacher and staff development $\left(X_{6}\right)$, process management $\left(X_{2}\right)$, and student and stakeholder focus $\left(X_{7}\right)$ which have successful contributed 65.60 percent variance of effectiveness of Thai World Class Standard Schools at 0.01 significance level with multiple correlation coefficient as $\mathbf{0 . 8 1}$. This study is to suggest factors that affect the effectiveness of Thai World Class Standard Schools.

Keywords: School effectiveness, World Class Standard School, administrative factors;

\footnotetext{
* ADDRESS FOR CORRESPONDENCE: Kanokorn Somprach, Faculty of Education, Khon Kaen University, Khon Kaen and 40002,
} Thailand. E-mail address: kanoklin@kku.ac.th / Tel.: +66-881166995 
Somprach, K., Prasertcharoensuk, T., \& Tang, K.N. (2016). Factor affecting the effectiveness of thai secondary world class standard school. International Journal of Learning and Teaching. 8(1), 20-29.

\section{Introduction}

Chapter 1: General Provision and Principles: Section 6 of the Thai National Education Act 2010 (Office of the National Education Commission, 2010: originated 1999, revised 2003) the main aim of the Thai education system is to fully develop the Thai people in all aspects including physical, mental, intellect, knowledge, morality, integrity, and a desirable way of life in order to live in harmony with other people based on Buddhist philosophy. Based on Clause 1, The Propulsion Policies in Education Reform, setting out a plan for 10 years, and Numbers 2-3: Institutional and Modern Age Learning Resources Development and World Class Schools Project, and the policy of the Ministry of Education (2010), the Office of Basic Education Commission of Thailand has to organize projects for World Class Standard Schools such as multi-integration projects which include management, academic management, vocational, and intellectual dimensions.

The main aim of the World Class Standard Schools is to develop $21^{\text {st }}$ century learners who are expected to possess good minds, language capabilities, technical skills, and soft skills according to the basic education core curriculum. In order to develop $21^{\text {st }}$ century learners, the country has to develop a meaningful curriculum which can be utilized by the learners to learn to know, learn to be, learn to do, and learn to live together as major principles. Subsequently, the Office of the Basic Education Commission of Thailand (2011) further clarified the definition of developing $21^{\text {st }}$ century learners as including improving their morality, preserving their Thai identity, developing creative thinking, fostering technological skills, assisting learners to be able to work with others, and to further assist them to be capable of living peacefully with other people and thus contributing to sustainable development.

According to the report from the Office of the Basic Education Commission of Thailand (2013), there are rapid changes taking place in the current teaching and learning process due to the assistance of technological tools such as the Internet, making the process of students' learning unlimited in terms of time and location. Traditional elements of the teaching and learning process like the imparting of teachers' knowledge and abilities in a physical classroom environment are no longer a necessity. Simultaneously, the transformation in economics, politics, science, and technology are directly affecting the Thai people's way of life in both urban and rural areas. School administrators should therefore develop the application of information and communication technologies to provide effective teaching and learning processes in order to enhance the learning of students.

In addition, this change in the current situation is needed in order to prepare Thai people for the ASEAN Community in 2015 in which education will become an essential mechanism for them to tackle the challenges of the change (Office of the Basic Education Commission of Thailand, 2013). As a consequence, this study aimed to examine the administrative factors that affect the effectiveness of Thai Secondary World Class Standard Schools in Northeastern Thailand. The significance of this study would be able to provide a substantial educational standard in accordance to World Class Standard and would assist Thai learners to be members of the global community. Apart from the consistency with Thai educational reform, the current study would be able to respond to the administrative policy of Thailand which focuses on human resource development.

\section{Background of the study}

The Thailand Quality Award (TQA) is planned to increase the competencies of organizational management up to the World Class Standard. Therefore the quality system for World-Class Standard Schools must have a system of excellence for organizational development as a representative characteristic based on TQA. World Class Standard Schools are developed according to the Baldrige Education Criteria for Performance Excellence which focus on systemic change through the system approach. The eleven core values of performance excellence have been integrated into seven factors 
of quality management which are stated as follows; leadership, strategic planning, students and stakeholder focus, measurement and analysis, knowledge management, personnel and staff focus, process management, and performance results. Each dimension is inter-related in terms of an integrated management system for Performance Excellence (Ministry of Education, 2010). The quality of educational management of World Class Standard Schools in the Thai context is basically focused on the learners' profiles to fulfill the standard set by UNESCO related to education; that is education managed in such a way as to produce potential world citizens in terms of their intellectual development and happiness as Thai people.

\section{Problem statement}

Wannasian, Keawsri, and Saksiri (2011) examined the current situation of educational management in the World Class Standard Schools. The focus of their study was on the obstacles and progress as well as making recommendations to improve educational management. The results of their study revealed that the quality of the World Class Standard School management system was good. However, their research outcomes also found that there was lack of clarity about teachers' functions as well as the an increase in teachers' workload. Teachers' workload not only increased in terms of curriculum and instruction as they are having heavier workload of teaching compared to before but also other additional activities. Furthermore, there are a few subjects that teachers have to teach in English, this would have led to increases in the time required for preparation as the language proficiency of the teachers is often not good. Therefore, teachers claimed to be overloaded thus affecting their readiness to achieve the goal of World Class Standard School.

On the other hand, the findings of Wannasian, Keawsri, and Saksiri (2011) indicated that students in World Class Standard Schools lacked inquiry skills and that this problem had been neglected due to their teachers' heavy workload. Nonetheless, Wannasian, Keawsri, and Saksiri monitored and assessed the quality management of World Class Standard Schools based on the four dimensions of curriculum and institutional development, learning management, quality management, and the quality of learners. Their findings showed that all four dimensions of quality management were at good level. An empirical study on the effect of administrative factors on effectiveness of World Class Standard Schools is a vital objective of future research.

\section{Research objectives}

The key objectives of this study as follow:

a) To identify the school principals' administrative factors and effectiveness in regard to three key outcomes of World Class Standard Schools namely organization, students and teachers in Northeast of Thailand.

b) To investigate the relationship between the school principals' administrative factors and the effectiveness of World Class Standard Schools.

c) To investigate predictors of the effectiveness of World Class Standard Schools.

\section{Research methodology}

The research population is 10,983 school principals and teachers from 111 secondary schools that had involved in World Class Standard Schools under the Office of the Basic Education Commission of Thailand, Ministry of Education in Northeast of Thailand. A total of 375 school principals and teachers were selected from 87 selected research schools by employing sample size determined by the Yamane Formula (1973). Meanwhile multi-stage sampling is engaged. 
Somprach, K., Prasertcharoensuk, T., \& Tang, K.N. (2016). Factor affecting the effectiveness of thai secondary world class standard school. International Journal of Learning and Teaching. 8(1), 20-29.

The instrument utilized in this study is a questionnaire consisting of 105 items containing 5 items of demographic information, 68 items linked to principals' administrative factors and 32 items concerning the effectiveness of World Class Standard Schools. Specifically, there are 68 administrative factors comprising 10 items relating to leadership, 8 items to process management, 7 items to strategic planning, 7 items to team building, 11 items to knowledge management, 7 items to teacher and staff development, 7 items to student and stakeholder focus, and 11 items relating to the use of information and communication technology. However, effectiveness of World Class Standard Schools consisted of three key outcomes, measured through 10 items describing effective outcomes measured from the students, 11 items from teachers and 11 items from the organization as a whole.

This questionnaire was delivered to a panel of experts for remarks and feedback. For validation purpose, these experts were nominated using standards based on their specialization in the area of leadership and holding administrative position as principal. The panelists elected comprised of seven professionals from numerous areas, such as three lecturers from the research and management department of Khon Kaen University, two academic experts from the Ministry of Education, Bangkok, one director from Educational Service Area, and one principal. From the feedback returned by the panel, some alterations were made to the original instrument.

The instrument was piloted to 30 principals who were not samples of the real study. They were elected because of their structure and population is similar with the real study. In order to improve the quality of the items in the instrument, they were also requested to provide suggestions and remarks on the items in the instrument. Adjustment was made based on the recommendations and advice. Therefore it could be concluded that the instruments were reliable and good to use as the Cronbach alpha value indicated that all the research variables had higher Cronbach alpha value than 0.985 .

Descriptive statistics comprising mean and standard deviation were applied in this research. Additionally, inferential statistic such as Pearson's correlation coefficients was used to describe the association between the school principals' administrative factors and the effectiveness of World Class Standard Schools. Finally stepwise multiple regression analysis was used to determine the principals' administrative factors that affect the effectiveness of World Class Standard Schools.

\section{Conceptual framework}

The variables in this research are illuminated in Figure 1. The variables include principals' administrative factors and the effectiveness of World Class Standard Schools. The administrative factors refer to the composition of systematic management aims to increase the effectiveness or quality of the World Class Standard. These aims relate to leadership, process management, strategic planning, team building, knowledge management, teacher and staff development, student and stakeholder focus, and the use of information and communication technology. These eight administrative factors are determined according to findings by Linder and Brooks (2004) on the identification for high performing organization as well as based on the Malcolm Baldrige National Quality Award (MBNQA) criteria (Baldrige National Quality Program, 2004).

On the other hand, the effectiveness of World Class Standard School refers to the outcomes which are found from students, teachers and organization perspectives (Office of Basic Education Commission, 2011). Student outcomes refer to characteristics such as communication skills (in Thai, English, and other languages), the use of technology (in learning, design, and presentation skills), creative thinking, social responsibility, skills in synthesizing information and world situations with respect to culture and traditions, and the ability to participate in competitions at the national and international levels. Moreover, students are expected to continue onto higher levels of education.

Additionally, teachers' outcomes refer to teachers' abilities such as organizing specific learning management, using foreign languages in teaching, applying advanced technology like technological 
media as a means of instruction, developing skills of teaching through team learning among themselves, utilizing classroom action research to improve their teaching, utilizing research, media and innovation in teaching, and continuing to improve their students' development. Finally, organizational outcomes refer to the system of quality management for World Class Standard Schools in terms of structure, cooperative culture, technology, and system management, which mainly focus on quality and results. As such, participation management was applied, prior attention was provided to teamwork, and knowledge exchange was used to create innovation and value added to the school organization.

The effectiveness of the three key outcomes is predicted to be related with principals' administrative factors. Figure 1 demonstrates the conceptual framework for this research. This framework also predicts that all principals' administrative factors promote effectiveness of World Class Standard Schools.

Independent Variable

Administrative Factors
- Leadership
- Process management
- Strategic planning
- Team building
- Knowledge management
- Teacher \& staff development
- Student \& stakeholder focus
- The use of information \&
communication technology

Dependent Variable

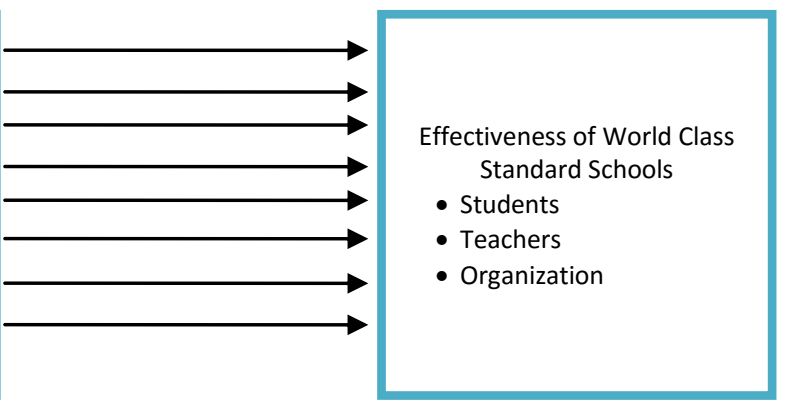

Fig. 1. Conceptual Framework

\section{Findings}

Table 1 beneath displays the identification of the level of variables recommended by Glass and Hopkins (1984). The levels of principals' administrative factors and effectiveness of World Class Standard School are identified according to the mean score ranges as indicated in Table 1.

Table 1. Interpretation of variable.

\begin{tabular}{ll}
\hline Mean score range & Interpretation \\
\hline $4.51-5.00$ & Highest \\
$3.51-4.50$ & High \\
$2.51-3.50$ & Medium \\
$1.51-2.50$ & Low \\
$1.00-1.50$ & Lowest \\
\hline
\end{tabular}

\subsection{Principals' administrative factors}

Table 2 shows the mean scores and standard deviation of the administrative factors of principals perceived by the respondents. As indicated in Table 2, the mean scores for all the eight administrative factors were at high levels, ranging from 3.72 to 4.22 . The highest perception level of agreement was strategic planning $(=4.22, S D=0.65)$. The next highest was leadership $(=4.16, S D=0.66)$. The same mean score as 4.15 was found in student and stakeholder focus $(S D=0.67)$ and team building $(S D=0.66)$. This is followed by the use of information and communication technology $(=4.07, S D=$ 
$0.66)$, process management $(=4.06, S D=0.65)$, and knowledge management $(=4.05, S D=0.66)$. The lowest mean score was teacher and staff development $(=3.72, S D=0.79)$. The overall perceptions toward the principals' administrative factor was at high level too ( $=4.07, \mathrm{SD}=0.60)$.

Table 2. Principals' administrative factors.

\begin{tabular}{llll}
\hline Administrative factors & $\begin{array}{l}\text { Mean } \\
\text { score }(\bar{x})\end{array}$ & $\begin{array}{l}\text { Standard } \\
\text { deviation } \\
(\text { ) }\end{array}$ & Interpretation \\
\hline Overall administrative factors & 4.07 & 0.60 & High \\
Strategic planning $\left(\mathrm{X}_{3}\right)$ & 4.22 & 0.65 & High \\
Leadership $\left(\mathrm{X}_{1}\right)$ & 4.16 & 0.66 & High \\
Student and stakeholder focus $\left(\mathrm{X}_{7}\right)$ & 4.15 & 0.67 & High \\
Team building $\left(\mathrm{X}_{4}\right)$ & 4.15 & 0.66 & High \\
The use of information \& & 4.07 & 0.66 & High \\
communication technology $\left(\mathrm{X}_{8}\right)$ & & & \\
Process management $\left(\mathrm{X}_{2}\right)$ & 4.06 & 0.65 & High \\
Knowledge management $\left(\mathrm{X}_{5}\right)$ & 4.05 & 0.66 & High \\
Teacher \& staff development $\left(\mathrm{X}_{6}\right)$ & 3.72 & 0.79 & High \\
\hline
\end{tabular}

\subsection{Effectiveness of World Class Standard School}

Table 3 displays the mean scores and standard deviation of the three key outcomes of effectiveness. As shown in Table 3, the mean scores ranged from 3.64 to 4.04 . This indicates that, the highest outcome was from organization $(=4.04, S D=0.69)$. This is followed by the second highest outcome from students $(=3.65, S D=0.74)$. The least effective outcome was from teachers $(=3.64$, $S D=0.74)$. Hence, referred to Table 3 , it can be determined that the effectiveness of World Class Standard School in actual situation, was high ( $=3.78, S D=0.66)$.

Table 3. Effectiveness of World Class Standard School.

\begin{tabular}{lll}
\hline Key outcomes & Mean score $(\bar{x})$ & $\begin{array}{l}\text { Standard } \\
\text { deviation ( ) }\end{array}$ \\
\hline Organization & 4.04 & 0.69 \\
Students & 3.65 & 0.74 \\
Teachers & 3.64 & 0.74 \\
Overall & 3.78 & 0.66 \\
\hline
\end{tabular}

\subsection{Correlation between school principals' administrative factors and the effectiveness of World Class Standard School}

Table 5 presents the Pearson correlation coefficient between the school principals' administrative factors and the effectiveness of World Class Standard Schools. According to De Vaus's (2002) interpretation of correlation coefficients as shown in Table 4, the correlation results between the eight administrative factors and the effectiveness of World Class Standard Schools revealed a significant and 
Somprach, K., Prasertcharoensuk, T., \& Tang, K.N. (2016). Factor affecting the effectiveness of thai secondary world class standard school. International Journal of Learning and Teaching. 8(1), 20-29.

positive association $(p<0.01)$, with strength of association fluctuating from 'substantial to very strong' and 'very strong'.

Table 4. Designation strength of association based on size of correlation coefficients.

\begin{tabular}{lll}
\hline Strength of association & Negative & Positive \\
\hline Low to moderate & -0.29 till -0.10 & 0.10 till 0.29 \\
Moderate to substantial & -0.49 till -0.30 & 0.30 till 0.49 \\
Substantial to very strong & -0.69 till -0.50 & 0.50 till 0.69 \\
Very strong & -0.89 till -0.70 & 0.70 till 0.89 \\
Near perfect & -0.99 till -0.90 & 0.90 till 0.99 \\
Perfect relationship & -1.00 & 1.00 \\
\hline
\end{tabular}

As designated in Table 5, World Class Standard School effectiveness was significant, positive and very strongly correlated with the use of information and communication technology $(r=0.75$; $p<0.01)$, knowledge management $(r=0.74 ; p<0.01)$, student and stakeholder focus $(r=0.73 ; p<0.01)$, and teacher and staff development $(r=0.73 ; p<0.01)$. In addition, it was substantial to very strong correlated with team building $(r=0.69, p<0.01)$, strategic planning $(r=0.68 ; p<0.01)$, process management $(r=0.64 ; p<0.01)$, and leadership $(r=0.64, p<0.01)$. This means that, to a great degree, a rise in the use of information and communication technology, knowledge management, student and stakeholder focus, and teacher and staff development is associated with a rise in the effectiveness level of World Class Standard School; and to a substantial to very strong degree, an improvement in team building, strategic planning, process management, and leadership is related with a rise in the effectiveness level.

Table 5. Correlation between administrative factors and effectiveness.

\begin{tabular}{lllllllll}
\hline Variables & X1 & X2 & X3 & X4 & X5 & X6 & X7 & X8 \\
\hline Leadership $\left(\mathrm{X}_{1}\right)$ & 1.00 & & & & & & & \\
Process management $\left(\mathrm{X}_{2}\right)$ & 0.77 & 1.00 & & & & & & \\
Strategic planning $\left(\mathrm{X}_{3}\right)$ & 0.81 & 0.81 & 1.00 & & & & & \\
Team building $\left(\mathrm{X}_{4}\right)$ & 0.81 & 0.78 & 0.84 & 1.00 & & & & \\
Knowledge management $\left(\mathrm{X}_{5}\right)$ & 0.78 & 0.77 & 0.81 & 0.87 & 1.00 & & & \\
Teacher \& staff development $\left(\mathrm{X}_{6}\right)$ & 0.61 & 0.62 & 0.60 & 0.66 & 0.73 & 1.00 & & \\
Student and stakeholder focus $\left(\mathrm{X}_{7}\right)$ & 0.76 & 0.73 & 0.79 & 0.82 & 0.85 & 0.69 & 1.00 & \\
The use of information \& communication & 0.71 & 0.70 & 0.75 & 0.79 & 0.83 & 0.72 & 0.84 & 1.00 \\
technology $\left(\mathrm{X}_{8}\right)$ & & & & & & & & \\
Effectiveness $(\mathrm{Y})$ & 0.64 & 0.64 & 0.68 & 0.69 & 0.74 & 0.73 & 0.73 & 0.75 \\
\hline
\end{tabular}


Somprach, K., Prasertcharoensuk, T., \& Tang, K.N. (2016). Factor affecting the effectiveness of thai secondary world class standard school. International Journal of Learning and Teaching. 8(1), 20-29.

\subsection{Significant predictor for effectiveness}

To recognize the significant predictor for World Class Standard School effectiveness, a stepwise multiple regression analysis was used. The eight administrative factors were treated as predictor variables, while school effectiveness was treated as the dependent variable in this analysis. The purpose of valuing this regression equation was to recognize the administrative factors that have significant effect on World Class Standard School effectiveness: that is, identifying the administrative factors which establish predictors for effectiveness.

The size of the standardized coefficient $(\beta)$ straightly specifies the prominence of these predictors relative to one another in this analysis. In the setting, the use of information and communication technology $(\beta=0.301)$ was the most vital predictor, followed by teacher and staff development $(\beta=$ $0.326)$, process management $(\beta=0.130)$, and student and stakeholder focus $(\beta=0.146)$, in that sequence. As shown in Table 6, the summary statistics of the estimated regression equation show the variables for which the coefficients are statistically significant.

The estimated regression equation was significant at $0.01(p<0.01)$, implying that all four predictor variables have an impact on the effectiveness of World Class Standard Schools; thereby qualifying these to be the predictors for the latter. In brief, these four variables have a linear relationship with the effectiveness of World Class Standard Schools. The adjusted $R^{2}$ being 0.656 in Table 6 shows that the impact of the use of information and communication technology was 57.0 percent, teacher and staff development was 7.0 percent, process management was 1.2 percent, and student and stakeholder focus was 0.4 percent. In conclusion, the four variables explain for 65.6 percent of variation in the dependent variable with multiple correlation coefficient as 0.81 . The following multivariate linear regression model shows the affiliation between the predictor variables on the dependent variable.

Table 6. Multiple regression of administrative factors on effectiveness.

\begin{tabular}{lll}
\hline Variables & Adjusted $\mathrm{R}^{L}$ & Change of $\mathrm{R}^{L}$ \\
\hline $\begin{array}{l}\text { The use of information \& } \\
\text { communication technology }\left(\mathrm{X}_{8}\right)\end{array}$ & 0.570 & - \\
Teacher \& staff development $\left(\mathrm{X}_{6}\right)$ & 0.640 & 0070 \\
Process management $\left(\mathrm{X}_{2}\right)$ & 0.652 & 0.012 \\
Student and stakeholder focus $\left(\mathrm{X}_{7}\right)$ & 0.656 & 0.004 \\
\hline
\end{tabular}

$* * \mathrm{p}<0.01$

Researchers concluded that these four variables can explain for 65.6 percent of variation in the dependent variable. The multivariate linear regression model below indicates the association between the predictor variables on the dependent variable.

Unstandardized score: $\hat{Y}=0.400+0.300\left(X_{8}\right)+0.272\left(X_{6}\right)+0.133\left(X_{2}\right)+0.146\left(X_{7}\right)$

Standardized score: $\hat{Y}=0.301\left(X_{8}\right)+0.326\left(X_{6}\right)+0.130\left(X_{2}\right)+0.146\left(X_{7}\right)$

\section{Discussion}

This research was mainly designed to examine the respondents' perception of principals' administrative factors and its impact on effectiveness of World Class Standard School. The descriptive findings revealed that school principals have implemented all eight administrative factors to a high degree. This is consistent with the findings of Chantaket (2011). Chantaket had studied only seven 
administrative factors, excluding the use of information and communication technology. However Chantaket's finding had showed that all seven administrative factors were at high levels.

School administrators need to have systematic management by applying the standards of the Malcolm Baldrige National Award or the Thailand Quality Award as a guidelines and framework in their administration (Office of the Basic Education Commission of Thailand, 2010). The findings from this study showed that Thai Secondary World Class Standard Schools have successfully created the awareness of these and integrated quality management to ensure the effectiveness of their organizations. Because of the current policies of Thai Ministry of Education in promoting the readiness and potential of World-Class Standard Schools to develop students, learning resources, learning environments, curricula, and instruction to promote lifelong learning, students are urged to have learning skills, critical thinking skills, and problem solving skills. Therefore current findings found to be relevant to the objectives of the Office of Basic Education Commission of Thailand which set the direction and aims in education reforms in the second decade 2009 - 2018 (Office of the Basic Education Commission of Thailand, 2011).

The finding of the relationship between principals' administrative factors and the effectiveness of World Class Standard School indicates that the correlation coefficient is positively related. In summary, among the eight administrative factors, there were four administrative factors which had very strong association with effectiveness while the other four administrative factors had substantial to very strong association with effectiveness. This is possibly due to the principal administrative factors being key factors in management and various tasks have been carried out in order to meet its target, in particular to improve the effectiveness of World Class Standard Schools. This means that practice should be in accordance with the set vision that focuses upon educational management in terms of learning needs of the students. Educational management should promote cooperative learning and create value for the teachers, staff, and other stakeholders. In addition, principals should be flexible in implementing changes, seeking, developing and utilizing knowledge and innovation based on management approach to develop students and teach them to be socially responsible and good future citizens. Prior attention should be given to value the success of the students and stakeholders. An overall perspective of the system which is linked to plans, key performance indicators, and activities should result in the integration of the school performance (Office of the Basic Education Commission of Thailand, 2010). This implication is consistent with Boonyakul's findings (2013).

According to the results from stepwise regression analysis, there are four administrative factors which have predictive power of 0.656 significantly at 0.01 level. As a result the four administrative factors namely the use of information and communication technology, teacher and staff development, process management, and student and stakeholder focus are able to predict the effective outcomes of World Class Standard Schools. In addition, the use of information and communication technology affects the most on effectiveness which is in line with the education policy of Ministry of Education (2010) thus has become an essential factor for the $21^{\text {st }}$ Century. This finding was found to be consistent with the findings of Eaton (2011). The evidence from this study shows that school principals should pay close attention to these four significant predictors since these four predictors are able to explain 65.6 percent variance of effectiveness.

\section{Acknowledgements}

This project was made possible with funding from Faculty of Education, Khon Kaen University. 
Somprach, K., Prasertcharoensuk, T., \& Tang, K.N. (2016). Factor affecting the effectiveness of thai secondary world class standard school. International Journal of Learning and Teaching. 8(1), 20-29.

\section{References}

Baldrige National Quality Program. (2004). Educational criteria for performance excellence. Retrieved December 25, 2014 from http://www.baldrige.nist.gov.

Boonyakul, H. (2013). A model of educational quality management for the excellence. (Unpublished doctoral dissertation). Burapha University, Thailand.

Chantaket, P. (2011). Model of management in World Class Standard School in Surin province. (Unpublished doctoral dissertation). Rajabhat Ubolratchatani University, Thailand.

De Vaus, D. (2002). Analysing social science data. London: Sage Publications Limited.

Eaton, S.E. (2011). Ten trends in $21^{\text {st }}$ Century education. Retrieved August 27, 2015 from http://wp.me/pNAh3OX.

Glass, G.V., \& Hopkins, K.D. (1984). Statistical methods in education and psychology. (2 ${ }^{\text {nd }}$ ed.). New Jersey: Prentice Hall.

Linder, J.C., \& Brooks, J.D. (October, 2004). 'Transforming the public sector'. Outlook Journal, 6(10), 68-76.

Ministry of Education. (2010). World-Class Standard School Instruction Guidelines. Bangkok: The Agricultural Cooperative Federation of Thailand.

Office of the Basic Education Commission of Thailand (2010). The manual for school quality management. Bangkok: The Agricultural Co-operative Federation of Thailand.

Office of the Basic Education Commission of Thailand (2011). World-Class Standard School Instruction Guidelines. Retrieved September 12, 2012 from http://www.edu.cru.in.th/ketsaraphan/loadfile/E/e4.pdf.

Office of the Basic Education Commission of Thailand. (2013). A guidelines for quality management with TQA. Bangkok: The Agricultural Co-operative Federation of Thailand.

Office of the National Education Commission. (2003). National Education Act 1999. Bangkok: Amarim Printing.

Wannasian, D., Keawsri, P., \& Saksiri, N. (2011). Research and development of World-Class Standard School Instruction. Thailand: Office of the Basic Education Commission

Yamane, T. (1973). Statistics: An introductory analysis ( $3^{\text {rd }}$ ed.). New York: Harper and Row. 